\title{
The basal metabolism of the newborn calf
}

\author{
By J. H. B. ROY* \\ National Institute for Research in Dairying, Shinfield, near Reading \\ AND C. F. HUFFMAN AND E. P. REINEKE \\ Departments of Dairy, and Physiology and Pharmacology, \\ Michigan State University, East Lansing, Michigan
}

(Received 30 March 1957)

The first measurements of the basal metabolism of the young calf were reported by Brody (1930), who used the indirect calorimetric method of measuring oxygen consumption by means of a closed-circuit spirometer. Determinations were made on forty-three calves of less than 3 weeks of age but most of the values obtained were restricted to ages of IO-2I days. No definite trends during the first 3 weeks of life were observed and with two calves values obtained on consecutive days from birth showed a high variability. Brody concluded, from a consideration of mean heat production at monthly intervals, that resting metabolism $/ \mathrm{kg}$ body-weight increased from birth to 2 months of age and decreased rapidly thereafter. When expressed on the basis of body-surface area, however, metabolism increased steadily to 6 months of age and then remained constant or tended to decline.

Blaxter \& Wood (I95 $\left.a, b, \mathrm{I} 95^{2} a, b\right)$ made a number of measurements of basalenergy metabolism of the young calf using the spirometer of Blaxter \& Howells (195 I), but only reported values obtained after the first 2 weeks of life.

Recently, Hawkins, Pope, Roy, Shillam, Ingram \& Greatorex (1957) have shown a marked change in pulse and respiration rate during the first 3 weeks of life of calves given $400 \mathrm{ml}$. separated colostrum followed by whole milk at the rate of $\mathrm{I} \mathrm{lb}$./ $\mathrm{Iol} \mathrm{lb}$. live weight and growing normally under the conditions of low 'infection' reported by Roy, Palmer, Shillam, Ingram \& Wood (I955). The mean pulse rate of forty-four calves, which was about I Io beats/min on the Ist day of life, fell rapidly during the Ist week and then more slowly to the value of $75^{-80}$ by the end of the $3^{\text {rd }}$ week. Respiration rates showed the same trend, falling from a value of 45 respirations/min on the Ist day of life to $22-25$ by the end of the $3^{\text {rd }}$ week. This pattern was similar to that found by Lewis \& Ralston (1953) for the concentration of plasma-proteinbound iodine in the calf.

As it is well known that the heat production of an animal is roughly proportional to its pulse rate, it seemed necessary to investigate whether this relationship was valid in the very young calf. If such a relationship did exist, it would indicate that the maintenance requirement of the calf during the first 2 weeks of life was considerably higher than during the $3^{\text {rd }}$ week.

* Working at Michigan State University under the auspices of a Kellogg Foundation Fellowship. 
An experiment was therefore made to determine the basal-energy metabolism of the calf during the first 3 weeks of life.

\section{METHODS \\ Calves and their management}

Four Holstein-Friesian calves, three males and one female, were used. All were born in February or March 1955 and were removed from their dams at birth before they had suckled. It was originally planned to give only sufficient colostrum to protect the calves from Escherichia coli infection, thereby avoiding any changes in heat production associated with a change in diet. Unfortunately, owing to the incidence of scouring, only the first calf (calf $M$ ) received a small amount of colostrum, namely $2 \cdot 5 \mathrm{lb}$., whereas the remaining three had colostrum given at the same rate as milk (see below) for $4-5$ feeds.

The calves were all given the same quantity of milk, calculated according to their metabolic body size, i.e. weight ${ }^{0 \cdot 73}$ (Brody, 1945), so that a $90 \mathrm{lb}$. calf was given $8 \mathrm{lb}$. milk daily and a I I $\mathrm{lb}$. calf received $9.5 \mathrm{lb}$. throughout the experimental period. The quantity of milk was fixed to supply sufficient energy for maintenance and a weight gain of about $0.5 \mathrm{lb}$./day (Roy, 1956). This rate of gain was aimed at partly to avoid scouring and partly in the hope that minimal levels of metabolism would be reached more quickly with a low rather than a high intake of milk. Marston (I948) showed that the minimal level of metabolism is reached more quickly when sheep are starved after low food intakes than when starved after high intakes. Similarly, Blaxter \& Wood $(1952 a)$ found that the heat production of a calf determined $15 \mathrm{~h}$ after a meal was greater when the amount of milk given to the calf before starvation had been high.

Feeding was twice daily, at I $\mathrm{a}$ a.m., after the determinations of heat production, and at 6 p.m. The mean composition of the whole milk was $3.2 \%$ fat and $8.7 \%$ solidsnot-fat. If scouring occurred, one feed was omitted and the quantity of milk given was reduced until the consistency of the faeces was normal. No determinations of basal metabolism were made unless the calf had received its full ration at the two previous feeds, except on two occasions when the calves were born after the time of the morning feed and determinations were made on the following morning.

The calves were bedded on sawdust and were weighed before the morning feed on alternate days throughout the experimental period of 3 weeks.

\section{Basal-metabolism determination}

Determinations of oxygen consumption were made on the calves ${ }_{5} \mathrm{~h}$ after their last meal with a Benedict-Roth-Collins spirometer of $16 \mathrm{~cm}$ diameter.

The calves were restrained in the normal sitting position with a rope passed round the hind-legs above the hock and then between the fore-legs and tied above the neck. This method has been used by us for a number of years to restrain calves, and a calf soon adapts itself to the routine. No measurements were made until at least 20 min after the calf had settled in the sitting position after restraint. Four replicated determinations of oxygen consumption, each lasting 6-1 2 min, were made daily, with some exceptions, during the first ro days of life and thereafter on alternate days. 
In calculating the heat production in calories, an R.Q. of 0.82 giving a caloric equivalent of $4.825 \mathrm{Cal} / \mathrm{l} . \mathrm{O}_{2}$ at s.t.p. was assumed. The disadvantage of this method of measuring heat production with its absence of an estimate of carbon-dioxide production and hence of R.Q. is well known, although it has been pointed out by Brody (1930) that the error should not in fact exceed $3 \%$. Moreover, Blaxter \& Wood (1952a) obtained R.Q. values of the order of 0.82 with two calves given a diet of whole milk.

Pulse and respiration rates were measured during each determination.

\section{RESULTS}

The results are given in Table $\mathrm{I}$ and Fig. $\mathrm{I}$. The mean heat production on each day is given in three forms for comparison with values in other publications, namely Cal./ $/ \mathrm{kg} / 24 \mathrm{~h}$, and Cal./sq.m surface area/24 $\mathrm{h}$ in Table $\mathrm{I}$, and Cal./ $/ \mathrm{kg}^{0.73} / 24 \mathrm{~h}$ in relation to pulse rate and respiration rate in Fig. I. Surface area was calculated from the equation of Brody (1945) as follows:

$$
A=0 \cdot{ }_{15} W^{0.56} \text {, }
$$

where $A=$ surface area (sq.m) and $W=$ weight (kg). The coefficient of variation of heat production for the four replicated determinations varied from $\mathrm{r} \cdot 8$ to $\mathrm{I} \cdot \mathrm{.} \cdot 6 \%$ with a mean of $6.9 \%$ for the whole experiment. All the four calves gained in weight throughout the 3 weeks, although the gain of calf $M$ was not significant. Brief details of factors that may have affected the results for each calf are given below.

Calf $\mathrm{M}$ (female): birth weight $91^{\cdot} \cdot 5 \mathrm{lb} .\left(4 \mathrm{I}^{\cdot} \cdot 5 \mathrm{~kg}\right.$ ); first basal-metabolism determination made $40 \mathrm{~h}$ after birth; scoured from 7 th to I Ith day of life. No determinations
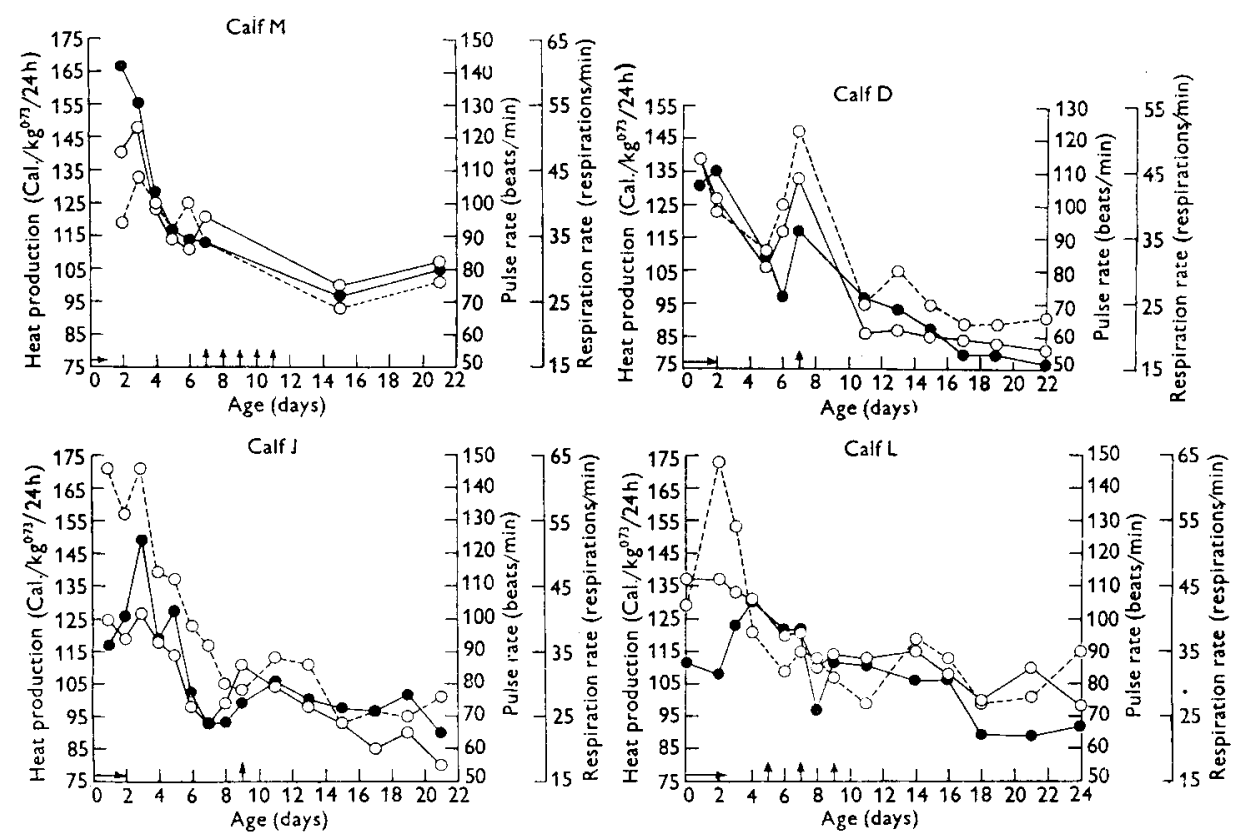

Fig. 1. Heat production, pulse rate and respiration rate of the four calves in relation to age.

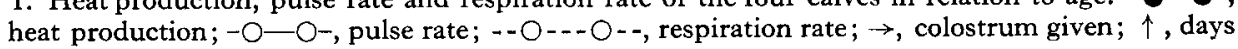
on which scouring occurred. 


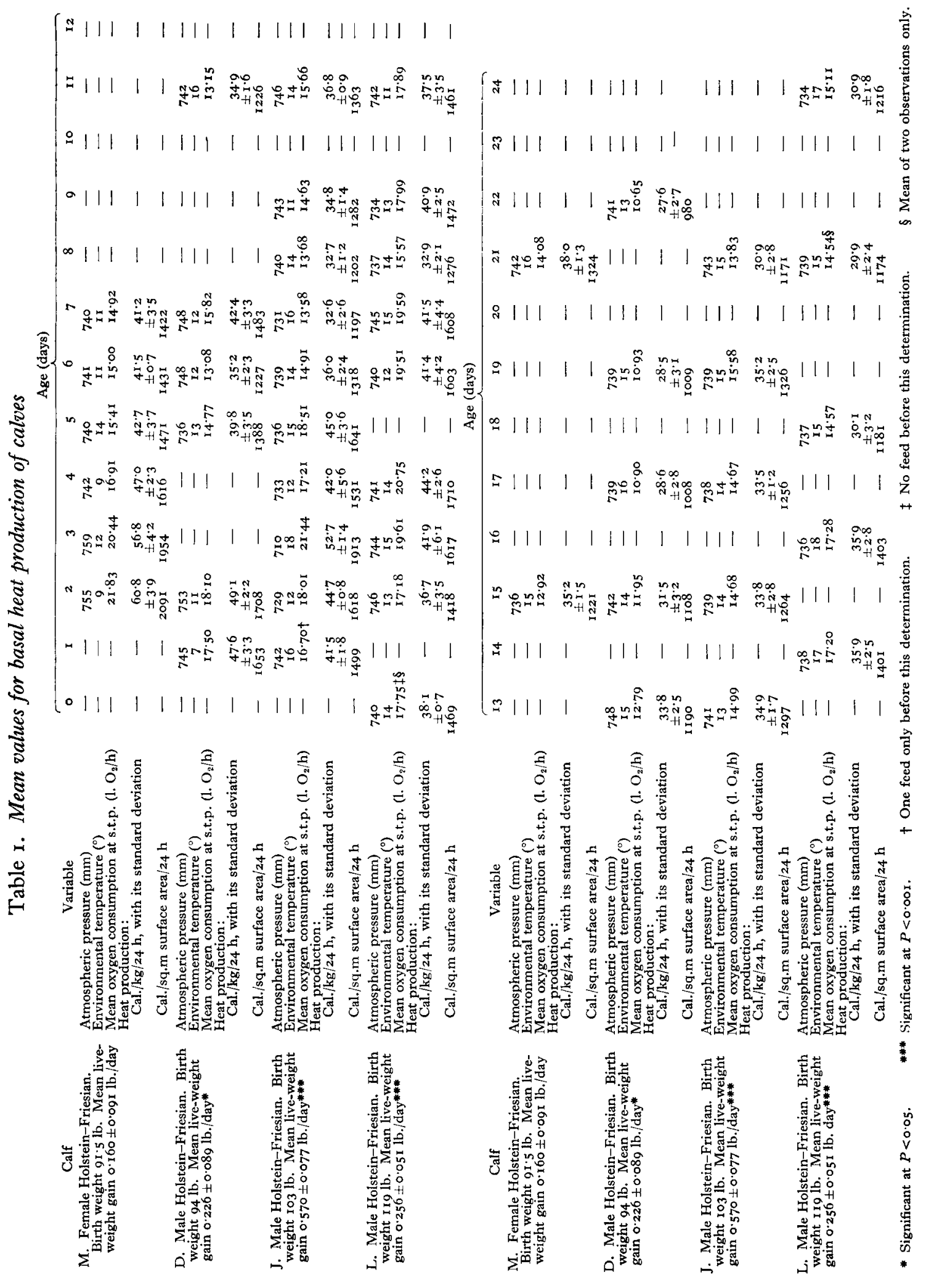


made between the 8 th and 15 th days; elevated pulse rate on the $7^{\text {th }}$ day, but oxygen consumption did not increase.

Calf D (male): birth weight $94 \cdot 0 \mathrm{lb}$. $(42 \cdot 5 \mathrm{~kg})$; first determination made $25 \mathrm{~h}$ after birth; scoured on the 7 th day only; elevated pulse and respiration rate on the 6th and $7_{\text {th }}$ days and increased oxygen consumption on the $7^{\text {th }}$ day.

Calf $\mathrm{J}$ (male): birth weight $103.0 \mathrm{lb}$. $(46.6 \mathrm{~kg})$; first determination made $23 \mathrm{~h}$ after birth; scoured on the $9^{\text {th }}$ day only, when pulse rate was increased and oxygen consumption slightly increased.

Calf $\mathrm{L}$ (male): birth weight I $9.0 \mathrm{lb}$. $(53.9 \mathrm{~kg})$; first determination made $0.6 \mathrm{~h}$ after birth. Although this calf scoured on the $5^{\text {th, }} 7^{\text {th }}$ and 9 th days of life, there was little indication that scouring had much effect on pulse rate or on oxygen consumption.

The mean values for basal metabolism of each calf expressed as $\mathrm{Cal} . / \mathrm{kg}^{0.73}$ and plotted against age in days in Fig. $\mathbf{I}$ indicated that heat production in general declined exponentially after the 2 nd day of life. The regression equation calculated from the determinations made after this time, after removal of between-calf variation, was as follows:

$$
Y={ }_{105} \cdot 9-48.03(x-0.9685), \text { S.E. }=9 \cdot 18,
$$

where $Y=$ heat production (Cal. $/ \mathrm{kg}^{0} \cdot 73 / 24 \mathrm{~h}$ ) and $x=$ age (log days).

The regression equations of pulse rate and respiration rate on age for the same period were as follows:

$$
\begin{aligned}
& Y_{1}=8 \mathrm{r} \cdot 6-43 . \mathrm{I} 8(x-0.9685), \text { S.E. }=8 \cdot 44, \\
& Y_{2}=33.9-26.47(x-0.9685), \text { S.E. }=5.82,
\end{aligned}
$$

where $Y_{1}=$ pulse rate (beats $/ \mathrm{min}$ ), $Y_{2}=$ respiration rate (respirations $/ \mathrm{min}$ ) and $x=$ age (log days).

All three regression coefficients were highly significant $(P<0.001)$. Fig. 2 gives the

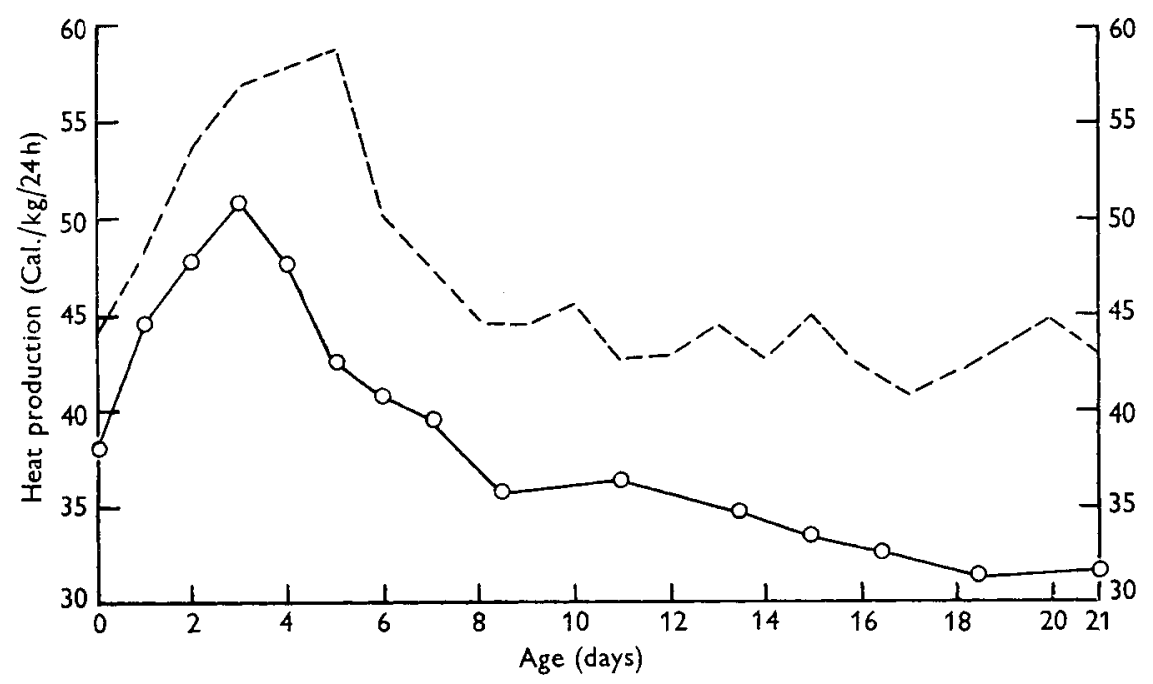

Fig. 2. Mean heat production of the four calves, $\mathrm{O}-\mathrm{O}$, in comparison with the results, - - - calculated from Brody (1930). 
trend in heat production ( $\mathrm{Cal} / \mathrm{kg} / 24 \mathrm{~h}$ ) over the period for comparison with the mean values calculated from the data of Brody (r930).

The results indicate that the basal metabolism of the calf, in whatever terms expressed, rose after birth to a peak between the 2 nd and 4 th days of life, fell quickly during the next 8 days and then more slowly throughout the remainder of the 3 weeks of the experimental period. The heat production thus did not follow the trend in pulse rate very closely until after the peak had been reached. It can be seen from Fig. I that there was some indication that the duration of colostrum feeding affected the time at which the peak of heat production was reached; the longer the duration the later was the peak.

In general, scouring caused an increased pulse rate without an equivalent rise in heat production.

The relationship between heat production and pulse rate for all the determinations, after removal of the between-calf variation, was as follows:

$$
Y=76 \cdot 3^{2}+0 \cdot 624(x-83 \cdot 7 \mathrm{I}) \text { or } Y=0 \cdot 624 x+24 \cdot 08, \text { s.E. }=\text { I0. } 19,
$$

where $Y=$ heat production (Cal./h) and $x=$ pulse rate (beats $/ \mathrm{min}$ ).

\section{DISCUSSION}

Before discussing the results, it is necessary to consider whether the conditions under which the determinations were made gave a valid estimate of basal, or at least minimal, heat production.

The main criticism that can be put forward is that disturbance to the calves during the determinations may have increased their heat production during the first 10 days of life. We think such an effect unlikely as in that event the pulse rate should also have increased. In fact the trend in pulse rate during the first 3 weeks of life reported here was very similar to that obtained in duplicate determinations by one of us with calves that were not disturbed by any experimental procedure.

Little information is available on the period of starvation necessary for the postabsorptive state to be reached, but Brody (1930) showed that in the 3-month-old pig this stage was obtained ${ }_{12}-\mathrm{I} 5 \mathrm{~h}$ after feeding, a period similar to that in man. Blaxter $\&$ Wood (195 $b$ ), however, with two Ayrshire calves more than 18 days old, found a very highly significant fall in heat production throughout a 4 -day starvation period, with no indication that the regression was curvilinear. Nevertheless, they conclude that this decline in metabolism was not due to failure to reach the postabsorptive state, as there was no marked fall in R.Q. during the fast and the peak of creatine excretion in the urine occurred early in the starvation period. They suggest that the decline in metabolism was probably due to a marked reduction in muscular tone. To demonstrate the trend in heat production with age in our experiment, it was not essential to do the determinations in the postabsorptive state as all calves were given identical quantities of milk on the basis of metabolic body size. Nevertheless, to obtain minimal values for comparison with those of other workers, the postabsorptive state was desirable. 
Whether our observations were made in a thermoneutral environment is also debatable. The lowest environmental temperature recorded at the time of the determinations was $7^{\circ}$. It may be below the critical temperature of the calf, although Brody (I930) has suggested that, except for the young pig, it is doubtful if temperature fluctuations greatly affect the metabolism of young farm animals. There was no indication from the results that low temperatures were causing an increased heat production in the calves. Kibler \& Brody (I949) have demonstrated that the range of thermoneutrality for adult dairy cows lies between $4.4^{\circ}$ and $15.5^{\circ}$ and it is possible that the temperature range is similar for young calves. Davis, Autrey, Herlich \& Hawkins (1954) showed that calves can tolerate low temperatures in an experiment in which calves exposed to temperatures as low as $-13^{\circ}$ grew as well as those that were housed, even though both groups received the same quantity of food. Similarly, in Russia normal growth has been obtained with calves exposed to temperatures of $-4^{\circ}$ to $+4^{\circ}$ (Vasilets \& Golushko, I95I).

From our results, it appears that the heat production of the calf increases after birth until a peak is reached between the 2 nd and $4^{\text {th }}$ days of life, in spite of the pulse rate being high at birth. After this time, the basal heat production falls rapidly until about 8 days of age and then more slowly throughout the rest of the 3 -week period, a trend that is in keeping with the change in pulse rate.

The changes in heat production during the first few days of life in the calf may be the result of its effort to adapt itself to its new environment, for it is known (Hawkins, 1956) that the body temperature of the calf does not reach its highest value, which is higher than that for an adult cow, until the and day of life. Once normal body temperature has been reached, pulse rate and heat production decline together. The relationship between heat production and pulse rate $(Y=0.642 x+24.08)$ is of the same order as that found by Blaxter \& Wood (r95 $\mathrm{I} b$ ) during periods of starvation of two Ayrshire calves, namely

$$
Y=0.644 x+10.46
$$

where $Y=$ heat production $(\mathrm{Cal} . / \mathrm{h})$ and $x=$ pulse rate (beats $/ \mathrm{min}$ ).

The mean values for heat production given in Fig. 2, calculated from Brody's ( $193^{\circ}$ ) values, showed that the greatest heat production occurred on the $5^{\text {th }}$ day. These calves were kept with their mothers for at least 5 days, and some, which were not doing well, for as long as a week. As the quantity of milk consumed by the calves was not controlled, the increase in heat production during the first 5 days of life might have been due to the increased quantity of milk ingested. The higher heat production for the calves of Brody (1930) throughout the 3-week period, was no doubt due in part to the higher intake of milk. In the experiment reported here, all the calves received a fixed amount of milk throughout the 3 -week period. It would seem unlikely that the higher intake of dry matter and protein from the colostrum would markedly affect heat production, especially as the heat production of calf $M$, which received only $2.5 \mathrm{lb}$. colostrum, was at its peak earlier than that of the remaining calves given colostrum over a longer period. From our results and those of Brody (1930) it seems possible that increasing the duration of colostrum feeding delays peak heat production. 
As far as we are aware, no attempt has been made to measure the oxygen consumption of the foetal calf, but the findings of Barcroft, Flexner \& McClurkin (1934) with the foetal and newborn kid show trends similar to ours. They showed a rise in oxygen consumption from a prenatal value of $2.5 \mathrm{ml} . \mathrm{O}_{2} / \mathrm{kg} / \mathrm{min}$ to several times this value immediately after birth, followed thereafter by a fall. Barcroft (1936) found that the foetal lamb consumed about $2.5 \mathrm{ml}$. $\mathrm{O}_{2} / \mathrm{kg} / \mathrm{min}$, whereas he cites a value for adult sheep of $5.7 \mathrm{ml}$. However, Barcroft, Kennedy \& Mason (I939) found a value of $4.3 \mathrm{ml} . \mathrm{O}_{2} / \mathrm{kg} / \mathrm{min}$ for the full-term lamb foetus and concluded that the earlier value of $2.5 \mathrm{ml} . \mathrm{O}_{2} / \mathrm{kg} / \mathrm{min}$ was too low. Expressed on this basis, the consumption of calf $\mathrm{L}$ was $4.8 \mathrm{ml} . \mathrm{O}_{2} / \mathrm{kg} / \mathrm{min}$ at $40 \mathrm{~min}$ after birth; the mean value for all four calves at the peak was $7 \cdot 3 \mathrm{ml} . \mathrm{O}_{2} / \mathrm{kg} / \mathrm{min}$. Carlyle ( $\mathrm{r} 946$ ), who estimated total oxygen consumption of the lamb foetus from the oxygen uptake of individual tissues, was unable to demonstrate any difference between the oxygen consumption of the full-term lamb foetus and a 6-day-old lamb. As has been pointed out by Barcroft (1946), this method of calculating oxygen consumption gives strictly basal values, which might be expected to be lower than that for the intact animal whose respiratory muscles are working and whose muscular system is in a state of tone. Thus, Carlyle's findings are not necessarily at variance with our own for he made no estimations of $\mathrm{O}_{2}$ consumption before the 6 th day of life when high values might have been obtained. The oxygen requirement of the human infant has been computed by Haselhorst \& Stromberger (1932) to be about $\mathrm{I} \cdot 5 \mathrm{ml}$. $\mathrm{O}_{2} / \mathrm{kg} / \mathrm{min}$ before breathing, whereas during the Ist week of life it is from 6.4 to $7.9 \mathrm{ml}$. (Schadow, 1932). From this rather scanty information, it would appear that the metabolic activity of the foetus in terms of oxygen consumption is probably lower than that immediately after birth.

Our findings may have some bearing on the function of colostrum other than that related to its high concentration of immune lactoglobulins and of most of the vitamins. The higher energy content of colostrum than of milk may be necessary to cover the high energy requirement of the calf over the first few days of life. The tendency for curvilinearity in the growth rate of calves, given small quantities of colostrum followed by a fixed amount of milk, when growing normally under conditions of low 'infection' (Roy, I956) adds further weight to this hypothesis. It is perhaps pertinent to consider whether the postnatal loss of weight in the young infant may be related not only to an insufficient intake of energy to cover its estimated maintenance requirement during the first few days of life (McCance \& Strangeways, I954), but also to a maintenance requirement that is higher during the immediate postnatal period than that generally accepted. However, the increase in heat production that appears to occur in ruminants after birth may have no parallel in a species born at a very different stage of physiological maturity.

\section{SUMMARY}

I. Four Holstein-Friesian calves were removed from the dams before suckling and after being given colostrum were reared on a standard amount of milk for the first 3 weeks of life.

2. Basal-metabolism determinations with a closed-circuit spirometer were made 
on the four calves ${ }_{5} \mathrm{~h}$ after a meal, usually at daily intervals for the first Io days of life and thereafter on alternate days.

3. Heat production increased for the first 2-4 days of life, then fell rapidly until the 8 th day, and thereafter more slowly. The fall in heat production from the 3 rd day of life was closely related to the fall in pulse rate.

\section{REFERENCES}

Barcroft, J. (1936). Physiol. Rev. 16, 103.

Barcroft, J. (1946). Researches on Pre-natal Life, Vol. 1. Oxford: Blackwell.

Barcroft, J., Flexner, L. B. \& McClurkin, T. (1934). F. Physiol. 82, 498.

Barcroft, J., Kennedy, J. A. \& Mason, M. F. (1939). F. Physiol. 95, 269.

Blaxter, K. L. \& Howells, A. (195I). Brit. F. Nutr. 5, 25.

Blaxter, K. L. \& Wood, W. A. (I95 I a). Brit. F. Nutr. 5, I I.

Blaxter, K. L. \& Wood, W. A. (195 I b). Brit. F. Nutr. 5, 29.

Blaxter, K. L. \& Wood, W. A. (I952a). Brit. F. Nutr. 6, I.

Blaxter, K. L. \& Wood, W. A. (1952b). Brit. F. Nutr. 6, 56.

Brody, S. (1930). Res. Bull. Mo. agric. Exp. Sta. no. 143.

Brody, S. (1945). Bioenergetics and Growth. New York: Reinhold Publishing Corporation.

Carlyle, A. (1946). F. Physiol. 104, 35 P.

Davis, L. R., Autrey, K. M., Herlich, H. \& Hawkins, G. E. (1954). F. Dairy Sci. 37, 562.

Haselhorst, J. \& Stromberger, K. (1932). Z. Geburtsh. Gynäk. 102, I6.

Hawkins, G. M. (r956). Unpublished work.

Hawkins, G. M., Pope, G. S., Roy, J. H. B., Shillam, K. W. G., Ingram, P. L. \& Greatorex, J. C. (I957). Unpublished work.

Kibler, H. H. \& Brody, S. (1949). Res. Bull. Mo. agric. Exp. Sta. no. 450.

Lewis, R. C. \& Ralston, N. P. (I953). F. Dairy Sci. 36, 363 .

Marston, H. R. (1948). Aust. F. sci. Res. B, 1, 93.

McCance, R. A. \& Strangeways, W. M. B. (1954). Brit. F. Nutr. 8, 2 I.

Roy, J. H. B. (I956). Studies in calf nutrition with special reference to the protective action of colostrum. Ph.D. Thesis, University of Reading.

Roy, J. H. B., Palmer, J., Shillam, K. W. G., Ingram, P. L. \& Wood, P. C. (1955). Brit. F. Nutr. 9, $\mathrm{I}$.

Schadow, H. (1932). Jber. Kinderheilk. $\mathbf{3 6} 6$, I.

Vasilets, Y. E. \& Golushko, V. G. (1951). Veterinariya, 28, 32. Quoted in Nutr. Abstr. Rev. (1952). 22. 271 . 